\title{
LisH Domain-Containing Protein FOPNL
}

National Cancer Institute

\section{Source}

National Cancer Institute. LisH Domain-Containing Protein FOPNL. NCI Thesaurus. Code C131320.

LisH domain-containing protein FOPNL (174 aa, $\sim 20 \mathrm{kDa}$ ) is encoded by the human FOPNL gene. This protein plays a role in ciliogenesis. 